\title{
Research on the development and prospects of the metal and textiles industries in Bosnia and Herzegovina
}

\section{Macroeconomic framework}

The main growth factors in Bosnia and Herzegovina in 2009 and in the first half of 2010 were domestic consumption and investment, whereas the contribution of foreign trade was, once again, negative. Domestic consumption recorded rapid growth, mostly due to public spending, while investment fell drastically compared to 2008. On the other hand, despite a significant weakening in the rate of import growth, the strong increase in the foreign trade deficit recorded in the previous year continued. The leap in world oil and food prices in 2008 and the first half of 2009, and a weakening in the demand for metals caused by the global economic crisis, were the most important factors increasing the deficit and thus slowing economic growth in $\mathrm{BiH}$ in 2009 and the first half of 2010.

It appeared originally that the global economic crisis would not be likely severely to affect economic growth in $\mathrm{BiH}$ in 2009, but events in the fourth quarter of 2008 represented the beginning of an increasingly intensive impact of the crisis on the $\mathrm{BiH}$ economy. The low growth rates of exports and imports in late 2009 indicated that foreign trade was the main channel of the effects of the crisis. The weakening of export demand affected metal production and the automotive industry most evidently and, in the fourth quarter, a fresh increase in the number of unemployed people was recorded after a long period of time, exceeding the psychological boundary of over 500000 unemployed. Ultimately, the cessation of deposit growth and the slowed credit growth in the fourth quarter represented only a prelude to developments in 2010 which were much less favourable.

It is expected that the global economic crisis, after reaching its peak in 2009, will have continued throughout the large part of 2010, which will significantly jeopardise economic growth in $\mathrm{BiH}$ during this period. In this respect, there are projections for a decline in economic activity in $\mathrm{BiH}$ (i.e. a real decline in GDP) of $2 \%$ in 2010 and then stagnation in 2011. The major contributing factor to the decline in GDP in 2010 will be the decline in disposable income and domestic consumption caused by the decline in exports and investment. The decline in global demand and metal prices, a lowering of export expectations and impeded investment financing will be the main factors behind change in both 2010 and 2011. Neither will recession be avoided in 2011, in spite of a strong decline in imports and a reduction in the foreign trade deficit.

Core inflation, with an annual rate of around $3 \%$, has been under the firm control of the monetary authorities for a number of years. The successful functioning of the Currency Board is the result of the cumulative effect of several factors: the high level of political support and public support for the reform of the monetary system; the substantial trust of the population in the reserve currency; the clear, simple goals of the 
Central Bank of Bosnia and Herzegovina $(\mathrm{CB} \mathrm{BiH})$ and its legal formation; legal restrictions on the activities of $\mathrm{CB} \mathrm{BiH}$ regarding the issue of money; the political independence of the Central Bank; and the transparency and accountability of the Board. In the decentralised fiscal system of $\mathrm{BiH}$, preserving the independence of the Central Bank represents a guarantee of monetary stability.

The main macroeconomic challenges facing $\mathrm{BiH}$ are fiscal in nature as well as oriented around foreign trade. They come down to:

- high level of public spending

- high budget deficit

- high public debt

- high current account deficit.

Over $60 \%$ of public expenditure is aimed at domestic public consumption, i.e. at employee remuneration and social benefits. These two categories have, in terms both of absolute and of relative value, recorded continued growth.

Indirect taxes or, more precisely, value added tax, represent a predominant source of the financing of public spending. The major importance of indirect tax revenues for budgetary revenues at all levels of government (indirect tax revenues ${ }^{1}$ account for almost one-half of total revenues of all levels of government in $\mathrm{BiH}$, and almost $55 \%$ of total tax and contribution revenues) is particularly evident when these are compared to the structure of public revenues in EU and OECD countries, especially in comparison with direct tax revenues. Therefore, a radical reform of the system of direct taxation is necessary.

High health care contributions are the result of a large part of the population not being formally employed; that is, the wages of a number of employed people are not reported in their full amount, while a significant number of the citizens is exempt from participation.

This leads the health care system towards a more heavy reliance on private sources of finance than is the case in EU member states. Due to a low level of per capita income, the health care system ends up with losses which remain outstanding (especially in the case of public hospitals).

High pension insurance contributions arise from a placing of the burden of payment on the relatively small number of employees who are actively insured. On the other hand, the number of pensioners, especially those that have not paid contributions over a sufficiently long period of time, is constantly on the increase (such that one-third of pensioners is below the age of 65). Therefore, there is a high dependency rate in the system (i.e. the ratio of pensioners to actively insured persons paying contributions), amounting to $60 \%$.

The result of the global economic crisis, which has led to a contraction in trade and other economic flows, is that the deficit is expected to swing to a level of $10 \%$ of GDP unless strong economic policy measures are taken.

1 Indirect tax revenues account for $45 \%$ of total revenues in BiH. In Brčko District, they account for $59.1 \%$; in the Federation of Bosnia i Herzegovina, $44.3 \%$; and in Republika Srpska, $42.2 \%$. 
The current account deficit is caused by large trade deficits. These are a consequence of a very narrow export base, especially in Republika Srpska, based on raw materials and their crude processing. The fifteen leading products account for four-fifths of exports. Progress in structural reforms should be aimed at supporting total factor productivity growth which should, in the present stage of economic development, already serve as a basis for the growth both of productivity and of exports.

The challenges in the next period will be in relation to external sustainability issues, i.e. the financing of the current account deficit of $\mathrm{BiH}$, and will be reflected in a reduction in capital inflows, foreign direct investment and remittances from abroad, and a drop in the number of foreign tourists, as well as in a reduction of exports due to a decline in demand and in the prices of base metals.

$\mathrm{BiH}$ does not have a developed and competitive export sector, which imposes the need for it to intensify activities towards encouraging its development in order that $\mathrm{BiH}$ products may qualify on the international market. Efficient and export- and marketoriented institutions, the rule of law, progressive education/training initiatives, a developed infrastructure, technological readiness and commercial innovativeness are essential prerequisites for effective participation in international trade.

The biggest obstacle to achieving the full potential of free trade in south-east Europe are non-tariff barriers, including complex regulations and product standards, rules on certificates of origin and burdensome customs procedures. Resolution of these nontariff barriers requires the active participation of a number of government agencies, private sector associations and individual companies, as well as a high level of international and regional co-operation.

$\mathrm{BiH}$ is recording a steady growth in foreign exchange reserves which have, in the past five years, ranged above the level of four months-worth of imported goods and services. Inflows from remittances from abroad, foreign direct investment and foreign bank liabilities have significantly contributed to the stability of foreign exchange reserves and of the Currency Board. However, in spite of this, the current account deficit has remained at a high level and, combined with the imbalance in government accounts, this poses a risk to macroeconomic stability.

The global economic crisis, which is increasingly leading to the depression of economic activity, requires fiscal incentives to stimulate aggregate demand and employment. Social crisis, arising from economic crisis, requires a careful balancing of measures in order to achieve redistributive effects to the benefit of those parts of the population which have lower incomes and earnings.

The fiscal deficit and assumed obligations require emergency measures towards the restructuring of budgets at all levels, with a view to ensuring their sustainability. Due to the inherited deficits from 2008 and 2009, a mild fiscal deficit should be targeted in subsequent years in order to ensure fiscal sustainability, according to EU criteria, during 2010-2013.

A restructuring of the budgets of the governments, aimed at reducing public spending and social transfers, will create room for the implementation of structural reforms, the relaxation of social contributions and a reduction in the labour tax burden in $\mathrm{BiH}$. Aligning the consolidated fiscal target of $\mathrm{BiH}$ with EU rules during the period of stabilisation and association represents a platform for fiscal consolidation that will enable 
a monitoring of the fiscal position of $\mathrm{BiH}$ by the $\mathrm{EU}$ and other international institutions (IMF, the World Bank) and, ultimately, a less painful integration of $\mathrm{BiH}$ into the EU.

Ensuring fiscal sustainability necessarily implies the establishment of efficient fiscal management. This is necessary to ensure that the Fiscal Council continues to function at full capacity. It should become the supreme fiscal authority in $\mathrm{BiH}$, with rules and decisions that will be binding on all levels of government. The activities of the Fiscal Council should contribute towards a strengthening of the fiscal discipline of $\mathrm{BiH}$ governments and the achievement of fiscal sustainability and monetary stability for $\mathrm{BiH}$.

Fiscal deficits and uncontrolled borrowing, as well as high current account deficits, could destabilise the monetary system and jeopardise the macroeconomic stability of the country. The measures that will be taken by $\mathrm{BiH}$ governments, as well as the system of inter-governmental fiscal relations as a whole, must be adapted to the conditions dictated by the existence of the Currency Board arrangement with a view to contributing to the stability of the currency and of prices.

The chosen path towards the EU and the obligations which have been assumed under the Stabilisation and Association Agreement, as well as other international obligations, impose on the $\mathrm{BiH}$ fiscal authorities the need to take on EU taxation standards and fiscal rules. They also require the implementation of tax reforms in the sphere of direct taxation and of other structural reforms in areas affecting the overall fiscal position of $\mathrm{BiH}$.

The rise in social entitlements granted to various categories of the population, especially in $\mathrm{FBiH}$, combined with the demographic problem of the ageing of the population and weak employment growth, has created enormous pressure on budgets. This was additionally strengthened following the last general election. The assumed obligations of war veteran and disability benefits, combined with an increase in the number of pensioners resulting from the relaxation of early retirement requirements as a means of resolving the question of surplus personnel stemming from the privatisation process or from bankruptcy and liquidation processes, represent a powerful generator of fiscal deficit.

Implementation of public administration reform, reform of the veteran social sector and the reform of pensions and disability insurance, ${ }^{2}$ as well as reforms in the area of health care and health insurance and in the area of employment, will contribute to fiscal consolidation and will create the necessary preconditions for the implementation of the structural reform of the economy, and of its public sector in particular.

Obligations towards the EU and the other international organisations pose both a threat and an opportunity. Rigorous international obligations and EU standards require sharp cuts in fiscal policy but, at the same time, they represent a catalyst for tax and structural reforms as well as being a cohesive and integrative factor in the management of public finances and the creation of a single economic space in $\mathrm{BiH}$.

The reduction in the size of the trade deficit, as well as the current account deficit, and the maintenance of a stable level of foreign exchange reserves, are the most important goals in the strengthening of the sustainability of the country's external accounts

2 Reform here has already been initiated in Republika Srpska. 
in the next medium-term period. On the other hand, private sector growth, coupled with stronger support for agricultural production, will enable the more effective substitution of imports with domestic products and services and will contribute in yet another way to a reduction in the trade deficit and in the current account deficit.

A decline in both exports and imports caused by the global economic crisis will lead to a reduction in the trade deficit in 2010 and, thereby, to a reduction of the current account deficit compared to 2009. However, in the circumstances of the expected reduced inflow from remittances from abroad, and in foreign direct investment and foreign bank liabilities, it will be significantly more difficult to finance the current account deficit.

The presence of banks with majority foreign capital has, in recent years, been exceptionally favourable as regards the strengthening of the banking sector and the stimulation of economic growth. However, it is under the circumstances of the existing global economic crisis that a dependence on capital inflows from foreign bank liabilities, which have already recorded a decline, represents an aggravation in the desire to maintain economic growth, the stability of foreign exchange reserves and the financeability of the current account deficit.

The current situation in $\mathrm{BiH}$ is characterised by there being two partially co-ordinated economic spaces (to which we should add Brčko District, whose regulations in the economic sphere are also specific), with unharmonised legislative and administrative systems. Due to a failure to comply with international rules regarding foreign trade, only an extremely small number of industrial products can be exported from $\mathrm{BiH}$ and a majority of exports are, therefore, raw materials and semi-processed products. On the other hand, due to the lack of adequate regulations and conformity verification systems for products, harmonised across the entire territory of the country, it is possible to import virtually anything into $\mathrm{BiH}$, including inadequate products and even those which are potentially harmful and dangerous to the health and lives of consumers. The weakest point in the quality infrastructure system is the technical infrastructure for conformity assessment (testing and calibration laboratories and certification and inspection bodies), in which no investment has been made for a long time.

None of the surrounding countries, or the EU, recognises the product conformity documents issued by operators from $\mathrm{BiH}$, while no bilateral or multilateral agreements on the mutual recognition of test reports and certificates have been signed. These are the main reasons why $\mathrm{BiH}$ is not able to use the advantages of the EU's exceptional trade measures adopted in September 2000, according to which it is possible to export almost all products to the EU virtually without quantitative and tariff barriers.

Establishment of a single economic space, based on the model of the EU, is a part of the Stabilisation and Association Process through which countries take on and apply in practice that part of the EU acquis related to the functioning of the internal market.

It is through the creation of the internal market, in accordance with the principles applied in the EU, that a number of important effects will be achieved:

- technical barriers to trade will be eliminated (compliance with relevant regulations on product safety) for all products exported to the EU market and, hence, to other national and regional markets in the world under the World Trade Organisation 
- the lives and health of humans and domestic animals, as well as the environment and consumer interests, will be protected to the maximum degree

- taking on and implementing measures from the priority negotiation chapters (industrial policy, small- and medium-sized enterprises, science and research, and education and training) will be combined with a building of the competitiveness of the $\mathrm{BiH}$ economy on the EU market as well as other national and regional markets.

The improvement and proper functioning of the $\mathrm{BiH}$ internal market are prerequisites for the implementation of any development strategy or policy, as well as for membership of the World Trade Organisation (WTO) and the European Union. The harmonisation of the economic space with that part of the acquis pertaining to the EU's internal market requires good organisation and a multi-disciplinary professional team in the departmental ministries. Only a good choice of priorities in taking on the $a c$ quis as it relates to the internal market would have a beneficial effect on the development of the economy and of society as a whole.

It is obvious that $\mathrm{BiH}$ faces a challenging path in creating a legal and economic system which is in accordance with EU standards and rules, but this is the only possible approach on the way towards becoming a full member of the Union and towards competing equally with the surrounding countries in the area of business activity and the attraction of investment. With a view to facilitating the overcoming of obstacles on this path and accelerating the association process, $\mathrm{BiH}$ should show greater appreciation of its own constitutional structure and make maximum use of the position of both entities, Brčko District and the country's local self-government units in the introduction of EU rules and standards, through the harmonisation of regulations and co-ordination of the dynamics of change.

In order to improve the flow of goods and services, as well as the factors of production (labour and capital), it is necessary to remove the numerous administrative obstacles and, above all, reduce the costs, procedures and time necessary for the registration of enterprises. It is also necessary to continue reforms in the fiscal sector related to direct taxation and social contributions, with a view to achieving a higher degree of the harmonisation of the tax legislation of the entities and Brčko District. This would help eliminate the harmful aspects of tax competition and contribute to an improvement in the business environment and to the potential for attracting foreign investors.

Fulfilling the obligations necessary for $\mathrm{BiH}$ membership of the EU requires the development of certain institutional capacities of the country and investing in certain areas. In addition to investing its own funds, $\mathrm{BiH}$ can access additional finance from other sources for the purposes of the European integration process. It is especially important to mention the pre-accession financial assistance of the European Union itself, i.e. its key financial instrument for 2007-2013, called the Instrument for PreAccession Assistance (IPA).

Assistance to $\mathrm{BiH}$ as a potential candidate country for EU membership is based on the priorities identified in the existing documents, i.e. the European Partnership; the reports and strategic documents contained in the annual enlargement package of the European Commission; and the Stabilisation and Association Agreement. For the purposes of the use of individual IPA components and programmes, it is necessary that 
$\mathrm{BiH}$ and the European Commission sign two agreements: the financial agreement; and the sectoral agreement. As far as the investment priorities are concerned, it is the key strategic documents constituting the policy framework for integration that define the objectives, i.e. the priorities for receiving the financial assistance of the Commission.

$\mathrm{BiH}$, as a beneficiary country for pre-accession assistance, is bound to ensure its own co-financing. The amounts of co-financing vary by individual IPA component and by the type of contracts embodied within the projects. Financial assistance is given in the form of grants, or otherwise as grants combined with loans from the international financial institutions. Foreign investment has, in the past ten years, considerably influenced economic development and represented a strong source of capital, influencing economic growth. Bosnia and Herzegovina has attracted a significant amount of foreign investment, but the majority of capital has been invested in taking over ownership shares, with the income used to close budget deficits. Bosnia and Herzegovina has neither a development strategy nor objectives for an adequate macroeconomic policy that could be used to implement such objectives. Therefore, neither the size of foreign investment nor its effects have reached the desired level.

The forty per cent decline in foreign direct investment compared to the previous year is a result of the pressure of the global financial and economic crisis as well as a consequence of almost completely exhausted privatisation opportunities and of structural weaknesses in the economy. This has led to a slowdown in the investment process. However, the most important reason for the decline in investment is represented by the internal problems of $\mathrm{BiH}$, the poor business climate and the authorities not being sufficiently involved in passing legislation related to doing business and the creation of a more favourable business environment in Bosnia and Herzegovina.

A slight improvement in the macroeconomic indicators might be a good sign of a gradual improvement in the general climate for foreign investment. Such positive results, after a long period of time, would encourage companies to extend their foreign investment plans in 2011 and beyond. This will, in turn, encourage a growth in the inflow of foreign direct investment. Even so, it is certain that this growth will be modest since it will be the result of the short-term impact of the special package of government measures offered at all levels in Bosnia and Herzegovina.

The overall economic situation in Bosnia and Herzegovina is characterised by the following issues:

- the process of the development of $\mathrm{BiH}$ is taking place in the context of an environment of increased international economic turbulence caused by the global economic crisis

- the $\mathrm{BiH}$ economy is in the process of strengthening the integrative flows of goods, services, capital, information and labour mobility in internal and external markets. This will enhance its exposure to the influence of, and competition with, its environment

- the political environment is dynamic. The announced forthcoming constitutional changes, in particular, will encourage further reform processes but, at the same time, they will also increase the risks to the functioning of the economy

- the economic environment is characterised by turbulence in the world food and energy markets and in demand for metals 
- the statistical framework in $\mathrm{BiH}$ is poorly developed and insufficiently compliant with the requirements of integration with the EU.

Textile industry in Bosnia and Herzegovina

\section{Background}

Due to the war and the complete isolation of the market in Bosnia and Herzegovina, industrial development retrogressed by some 10-15 years, and even more in some branches of industry, such that the development cycle had to start from the very beginning. It was frequently the case that markets which had previously been captured by the country were taken over during the war by those who were not in the war since they were not experiencing any resulting disruptions in the development cycle.

The rapid privatisation of conglomerate companies in the former socialist economic systems of Poland, Czech Republic, Slovakia, Hungary and Romania, with the participation of foreign investors in the purchase of companies or the establishment of new companies, created a new reality in production and on the market for textiles products. It was, in particular, German shoe factories and companies producing footwear parts and materials that utilised the favourable opportunities for establishing new factories, or taking over existing ones, in these countries.

Compared to the other countries of south-east Europe, however, Bosnia and Herzegovina has received less foreign direct investment. Foreign companies are only prominent as principals, with a $95 \%$ share being held by Italian companies.

In comparison to other countries, Slovenia stands out with respect to its involvement in Bosnia and Herzegovina. The Slovenian shoe manufacturer Alpina purchased and privatised the shoe factory Fogs in Sarajevo. In Bosnia and Herzegovina, Alpina acts very frequently as a principal in outwards processing arrangements. Among others, the shoe factories KTK from Visoko and Lišto from Šroki Brijeg produce for Alpina. Slovenian investors know this region very well and have the necessary language skills that they can avoid the existing bureaucracy.

Around $80 \%$ of Slovenian investors have focused on the countries of south-east Europe. In the short-term, however, very few opportunities can be seen for foreign investment or the establishment of new textiles factories in Bosnia and Herzegovina. The sector is burdened by huge capacities, with a load currently estimated at a level of $30-40 \%$ of capacity. In addition, experience shows that it is investors from countries with high purchasing power which are the ones getting involved. These include, among others, investors from Slovenia, Greece, the Czech Republic and Hungary but, for now, they are not focused on Bosnia and Herzegovina.

In the area of the manufacture of other leather products and accessory parts, there are many active small private crafts-based enterprises. However, data about these do not exist.

The textiles and clothing industry in Bosnia and Herzegovina is largely privatised and fragmented, with a dominant share of small- and medium-sized enterprises in the total number of entrepreneurs. Similar to the industry in the EU, it is going through a period of intense change and structural adjustment. 


\section{Performance}

Production in the textiles and clothing industry declined by $30.2 \%$ in 2009 compared to the 2000 level. The decline in production is a result of the transition and market liberalisation under which strengthened competition from imports led to a weakening of the position of domestic manufacturers. The stated decline was reflected in a decline in the number of employees. Even so, there are differences in individual production activities such that growing, stagnant and declining activities can be identified.

Productivity in the textiles and clothing industry is significantly lower than the overall level of productivity in the economy and it averages just $38.4 \%$ compared to the gross value added per employee in the economy as a whole. Labour productivity reflects a passive, i.e. defensive, restructuring wherein it is the reduction in employment that is the main source of labour productivity growth.

Wages in the textiles and clothing industry are high in comparison with developing countries and, as such, they pose a barrier to the achievement of price competitiveness. However, they are low compared to the rest of the economy in Bosnia and Herzegovina and are therefore not sufficient for the motivation of employees or the attraction of the necessary experts, or in terms of sending the right market signals concerning a shift in the structure of production towards higher value added products.

The recorded low level of profitability has resulted in unsatisfactory levels of the essential quantitative and qualitative business indicators, as explained below. The analysis of business performance by individual sections and sub-sections indicates a differentiation between the relatively higher success rates in the manufacture of knitted and crocheted articles and the manufacture of other outerwear.

In the 2003-2009 period, total turnover in the textiles and clothing industry shrank in the domestic market and in exports. There is an evident loss of price-oriented customers on the one hand and a loss of customers with higher purchasing power on the other.

There are, however, differences between individual product groups.

It has been established from specific research that the $\mathrm{BiH}$ textiles and clothing industry operates traditionally within the existing market structure. The majority of $\mathrm{BiH}$ manufacturers are oriented towards mixed production with a significant share of outwards processing arrangements (so-called lohn arrangements).

Companies oriented towards outwards processing have prices set in advance and are able to access know-how from foreign buyers, so have a lesser need to invest in research and development. Companies manufacturing their own products achieve higher prices and realise higher profits per employee compared to those in outwards processing arrangements (although outwards processing is profitable in its entirety). It turns out that the development of companies' own products requires greater investment in product development, the marketing of own brands and the development of an individual sales network.

Such a manufacturing orientation enables the realisation of higher profitability per employee, higher productivity and, thereby, the paying of higher wages.

In general, it can be said that the existing situation in the textiles and clothing industry results in lower investment in development and marketing. Very few companies 
have formally-established units dealing with research and development. There is a low level of development of own brands, representing an important factor in the improvement of image and market position. Companies do not monitor or know the market sufficiently well, especially not in terms of developments in the global market.

The next most important market problem facing the $\mathrm{BiH}$ textiles and clothing industry is distribution. The present state of distribution is unsatisfactory and it is, therefore, an inefficient model. Such weaknesses in the market aspects of business activity contribute to an inefficient market position and the low levels of efficiency in the industry overall.

An analysis of foreign trade in the textiles and clothing industry has shown that Bosnia and Herzegovina has, during the transition period, lost its comparative advantage for a significant number of textiles and clothing products. There is a causal connection between the loss of its comparative advantage and slow structural adjustment, i.e. the restructuring that has, ultimately, resulted in a collapse in the export of a significant proportion of the output of the textiles and clothing industry to the EU market.

The somewhat more prominent growth of exports in the past few years to the market of the former Yugoslav republics has alleviated, to some extent, the decline in total exports. However, this growth has not been sufficient to compensate for the loss of comparative advantage on the EU market, which is the dominant market for textiles and clothing in the international trade of Bosnia and Herzegovina. A heavy concentration of exports is an indicator of an insufficient diversification of export programmes, as well as an under-representation of the textiles and clothing industry in foreign markets.

Within the structure of the export of textiles and clothing products, three product groups contribute more than two-thirds of exports. Such a structure increases exposure to the risk of the loss of markets and of falling competitiveness. There is a causal connection between the low added value of $\mathrm{BiH}$ exports of textiles and clothing products and those exports which are based on outwards processing arrangements, based on under-representation and the poor recognisability of domestic brands in international markets.

Due to the loss of the raw material base in the domestic market that occurred during the transition period, the majority of domestic manufacturers are condemned to purchase raw materials and supplies on international markets which, ultimately, contributes to the decline in export price competitiveness. The causes of the lagging behind in the export competitiveness of the textiles and clothing industry lie in the amount of backwardness in the area of innovation, research and development, permanent education and the creation of a stimulating environment that would motivate entrepreneurs and companies to increase the level of competitiveness.

Competitiveness in the textiles industry can only be maintained through insisting on investment in technology that enables higher levels of productivity and product quality in which innovation, creativity and design are factors of key importance. 


\section{Strategic challenges for the BiH textile and clothing industry}

The textiles and clothing industry in $\mathrm{BiH}$ does have prospects. One of the essential prerequisites for achieving these is the identification of, and positioning towards, profitable market niches to which small and flexible production units with higher technological levels are adapted. Such a production structure must be based on the development of brands. It could be stressed that market repositioning, with a focus on higher value added products, offers an opportunity for income growth and the development of a profitable industry. The key essentials for this include entrepreneurial spirit, active partnership and the co-operation of entrepreneurs in the production of a recognisable supply. It is important to insist on an organised and planned approach and provide opportunities to entrepreneurs who will, due to their innovativeness and management skills, raise the level of competitiveness of this industry.

The preliminary results and conclusions of an analysis of the causes of the loss of comparative advantage suggest that it is necessary to insist on the implementation of measures to strengthen competitive position. Provided that the already discussed prerequisites are created, it is possible to preserve the identified competitive advantage in exports and, following appropriate restructuring at company level, to strengthen both comparative and competitive advantage.

The loss of comparative advantage is particularly noticeable in the primary textiles industry. The decline in competitiveness and loss of comparative advantage in this segment of the textiles industry has resulted in a significant decline in employment and the closing down of individual production programmes. Such trends could, to a large extent, be attributed to a poor privatisation model, accompanied by an insufficient level of the capital investment necessary for the modernisation of manufacturing processes and programmes. The statistics show that Bosnia and Herzegovina has, currently, only one modernised spinning mill and only three modernised weaving mills, one of which has been in bankruptcy for five years.

The growth of the importing of textiles and clothing products, as well as unsatisfactory possibilities for the implementation of protective measures of economic policy in the form of subtle measures (such as the control of the application of eco-standards for imported goods), seriously hinder the sales of domestic manufacturers on the $\mathrm{BiH}$ market. Thus, there is a need for a consistent development policy in the textiles and clothing industry sector in order that Bosnia and Herzegovina may be able to use its available resources as quickly as possible.

Leading corporations in the textiles and clothing industry are, in markets dominated by globalisation processes, focused on the rationalisation of expenditures with a view to raising their level of competitiveness in export growth. Based on existing research findings, it can be expected that the success of domestic textiles companies in the international market and of export trends will, in the coming period, depend primarily on innovativeness and vision, as well as responding to new challenges and instituting rapid and effective development. There is a need for the continuing bringing forward of new programmes and products; while it is necessary also to adjust to emerging needs and demands in the international market.

A successful market approach necessitates the modernisation and restructuring of manufacturing processes. Consequently, it is of utmost importance that companies de- 
velop their own product brands and compete in the market with them. Simultaneously, the key challenge to economic policy in the area of the textiles and clothing industry is to create favourable conditions for business based on investment in the development and application of modern manufacturing processes, as well as the development of new brands.

Globalisation and integration processes, and the dismantling of trade barriers, bring both opportunities and threats to the development of Bosnia and Herzegovina's international trade in textiles and clothing products.

The $\mathrm{BiH}$ market is small in size and with a relatively low purchasing power, such that most textile industry companies are oriented towards exports, mainly to the demanding EU market. Added value is found at a low level and only achieved through the export of textiles and clothing products. The reasons for this lie, inter alia, in that most $\mathrm{BiH}$ textiles companies manufacture products that are sold under other trade names and do not have their own developed recognisable brands that would allow for their greater profit. A low added value results in an insufficient accumulation of companies' own capital necessary for the development of their own brands, which require large investment in marketing and promotion. In the type of outwards processing (lohn) arrangements that dominate the export structure, however, it is necessary to achieve the standard production quality requested by the foreign buyer. This imposes the need for the continuous modernisation of manufacturing processes, which ultimately results in improved product quality.

The threat to maintaining and increasing exports based on outwards processing (lohn) arrangements stems from the constant competitive contest which is compelling western European manufacturers to reduce costs by moving their production to Asia, southern Europe and, more recently, to central and eastern Europe. The moving of production capacities to countries with low labour costs is taking place in both the textiles and the clothing industry. Up to now, the countries of central and eastern Europe have proven to be a better choice for the construction of manufacturing plants, primarily due to their geographical proximity and the availability of skilled labour that can ensure the meeting of the appropriate quality standards.

On the other hand, market liberalisation, substantial imports of finished textiles products and a dependence on imported fabrics and business conditions in the domestic market have had, inter alia, a pronounced effect on the decline in competitiveness of the textiles and clothing industry. A greater openness and liberalisation of the domestic market will result in a greater exposure to influences and trends in the international market, as well as in a strengthening of competition in the domestic market. Currently, the level of quality and standards of the textiles and clothing products which are being imported into $\mathrm{BiH}$ is significantly lower compared to their level in EU countries. It is by setting high standards for, and using strict quality control of, imported goods that EU countries are able to protect their markets from dumping, unfair competition and a decline in the quality of products available on the market. The same standards apply to their own manufacturers as well, thereby encouraging the high quality of products manufactured in the EU which, ultimately, results in an increase in manufacturers' competitiveness in the international market. 


\section{Summary and recommendations}

In concluding our discussion on the existing situation and the importance of the textiles and clothing industry to the $\mathrm{BiH}$ economy, the following can be said:

- the share of the textiles and clothing industry of gross value added and of employment in Bosnia and Herzegovina suggests it has still a significant but, at the same time, a continuously decreasing importance for the economy as a whole

- looking at the trends in the textiles and clothing industry, it can be said that these have recently shown a significant deviation in Bosnia and Herzegovina to what is happening in European Union member states

- productivity in the textiles and clothing industry of Bosnia and Herzegovina is growing at rates that are lower than in the old EU member states, but the growth stems from employment declining faster than output

- productivity growth in the textiles and clothing industry in Bosnia and Herzegovina and in the European Union is slower than productivity growth in the rest of the economy

- average wages in the textiles and clothing industry in Bosnia and Herzegovina lag significantly behind wages in the rest of the economy, but they also lag behind productivity. This indicates that the problems of the textiles and clothing industry are serious in nature and that a general approach to increasing competitiveness through wages rising more slowly than productivity growth will, in the case of the textiles and clothing industry, not resolve in any substantial way the problem of the overall competitiveness of this industry

- this is an industry in which gross wages represent a significant portion of expenditure, so that it is necessary to consider in full the effects of an increase in the socalled minimum wage at the national level in order to avoid any negative consequences for employment.

Trends in the textiles and clothing industry in Bosnia and Herzegovina will significantly depend on the ability of $\mathrm{BiH}$ manufacturers to resist competition from manufacturers coming from countries with lower production costs. It is therefore critically important to insist on changing the structure of textiles and clothing products, i.e. to insist on an orientation towards the manufacture of high value added products. Relying on price competition and production with a view to minimising costs, instead of seeking ways to increase value added, would, in current market conditions, condemn the entire industry to slow extinction.

Given the market structure, the requirement for restructuring is aimed at orienting production for final use in a target market that includes domestic and European households with medium purchasing power. Depending on their positioning in a particular market niche, it is possible that individual manufacturers could reach the level of European high fashion. However, with respect to the $\mathrm{BiH}$ textiles and clothing industry as a whole, that would be a very ambitious goal given its investment potential and market structure. It should be noted that even achieving the objective of restructuring production in favour of high-quality products intended for the broader market requires significant investment in the upgrading of technology, following fashion trends, design and marketing. 
It is an insistence on quality and contemporary design that should be basic distinctive characteristics vis-à-vis cheaper competition coming from the east. On the way towards accomplishing this objective, the grouping of manufacturers into independent, formally highly flexible but, above all, collaborative company clusters would contribute to a much greater likelihood of their success than would be the case with the individual un-coordinated attempts of each manufacturer to win small market shares, wherein they would frequently compete directly with each other.

Globalisation affects the inclusion of previously-isolated geographic regions into international trade flows. Given the difference in wage levels and purchasing power, European countries, including Bosnia and Herzegovina, can no longer be competitive in the manufacture of products in which the most important input is simple labour, as is most frequently the case in outwards processing (lohn) arrangements or in the manufacture of simple textiles and clothing products. The dynamics of exiting outwards processing (lohn) arrangements will depend on there being improvements in financial liquidity and in access to financing across the entire sector, since this sort of arrangement is currently being used to bridge the liquidity gap in the $\mathrm{BiH}$ textiles and clothing industry. Bosnia and Herzegovina will gradually, like other European countries, irreversibly lose its share of the group of textiles and clothing products which is characterised by simple processing, a low quality level and consequently a low price.

A comparative advantage of the $\mathrm{BiH}$ textiles and clothing industry is its proximity to the European market, both in geographical terms and in terms of climate and sociocultural environment, as well as in terms of the similarities in aesthetic attitudes, i.e. attitudes towards the design of textiles and clothing products. The proximity to a leading textiles and clothing market, such as the EU, and to knowledge clusters and manufacturers of leading equipment, as well as the traditional orientation of the $\mathrm{BiH}$ textiles and clothing industry towards this market, all represent certain comparative advantages. In addition, proximity to the European market ensures the prompt and flexible response of manufacturers to changes in European demand as regards their distribution possibilities and the manufacture of smaller, higher-quality batches.

Competitiveness in the textiles and clothing industry can only be maintained through insisting on investment in technology that enables higher levels of productivity and product quality, wherein innovation, creativity, design and fashion are of key importance. Incentives should also focus on investment subsidies, especially those for research and development, as well as for activating the sector of small- and mediumsized entrepreneurs whose flexibility can significantly support business activity across the entire chain of manufacturers in the textiles and clothing industry.

It is necessary to respect EU priorities, where education and increased employability play significant roles. It is precisely that orientation towards higher quality products that requires a continuing learning by employees, both in terms of their ability to adapt to fashion trends and in terms of the application of modern manufacturing technology, requiring an ability to adapt quickly to new techniques.

The expected continuation of the process of restructuring of the textiles and clothing industry must include, and to a much higher extent, the set of activities aimed at the identification of appropriate market opportunities and carried out through achieving higher levels of working equipment and developing products that correspond to the 
identified opportunities. Ultimately, the same efforts are expected to be made in the sale of such products, with the final result of increasing levels of value added. Based on the opportunities seen in this perspective, it is possible to define the fundamental elements for the success of the $\mathrm{BiH}$ textiles and clothing industry.

The growth in sales of own products contributes to higher prices and higher profit per employee. In comparison to outwards processing arrangements, a market orientation of companies towards their own products also implies higher expenditures, i.e. greater investments in marketing, brand development and research \& development. Profitability can be achieved through a quantitative growth in production and sales but, at the same time, it is possible to achieve increased profitability in a group of small manufacturing plants, which may represent a specific comparative advantage provided that profitable market niches can be identified. This requires a more active approach in the monitoring of market trends, investing in employees and their knowledge as well as in the appropriate level of manufacturing equipment, and maximum production flexibility.

Intensifying marketing activities both in the domestic and the export markets will positively affect sales growth. However, marketing activities require adequate investment and appropriate personnel. With an increase in labour productivity, it would be possible to perform such a reallocation of resources.

Demand in the region exists in terms of import substitution, export growth and the finding of new markets. Positive factors affecting demand are as follows: consumption market growth and productive consumption market growth. Special importance is attached to market segmentation and the successful identification of profitable market niches.

The market offers opportunities for growth of sales turnover through the increase of sales to existing customers and the acquisition of new customers. Provided that the $\mathrm{BiH}$ textiles and clothing industry increases its competitiveness, it is possible to raise profits at the expense of imports and achieve sales growth, particularly in foreign markets. It is necessary to insist on the identified comparative advantages in international trade and recover comparative advantage in product groups which offering realistic opportunities to do so.

\section{BiH metal industry}

\section{Background}

The metal sector in Bosnia and Herzegovina is characterised by a very low level of capacity utilisation, old equipment, limited possibilities for attaining the investment level necessary to improve productivity and a lack of available raw materials. The interentity division of the $\mathrm{BiH}$ economy has resulted in the complete disintegration of the internal market which, additionally, has hampered the possibility of the successful recovery of production.

The other substantial problem lays with the registering of pre-war employees in companies as 'temporary laid-off workers'. This stems from the obligation of companies to calculate and pay social security contributions (pensions, health and unemployment insurance) for such workers, i.e. people that were not participating in the pro- 
duction process because there was, at the time, no need for them as a result of the low levels of capacity utilisation.

\section{Privatisation}

The privatisation process was another very important legal obligation of companies in the 1998-2002 period. Companies were bound to prepare their initial balance sheets and privatisation programmes as the basis for their privatisation. Privatisation was, in the first phase, realised through the sale of those assets that did not have an important role in the running of the main lines of businesses or technological units (small privatisation). This was followed by large-scale privatisation, based on a public offering of shares.

Research shows that tender privatisation, with companies having found strategic partners for themselves, had the best results in the metals sector in companies that had been faced with a loss of markets, i.e. those that did not have the ability to secure initial capital for (re-)starting production on their own. Examples of companies belonging to this group are: PS CIMOS TMD Ai Gradačac; Mittal Steel Zenica; the joint stock company Pipe Factory Derventa; and the joint stock company Dalekovod TDS Doboj.

The second group of companies included companies in the privatisation process that were bought by their employees and management. They have, through their operation, quality production and timely deliveries, managed to capture both domestic and foreign markets.

In the period following 2001, some companies in the metals sector made great progress in terms of completing the privatisation process through finding strategic partners. After signing privatisation contracts, these companies carried out restructuring; acquired new equipment; resolved the status of their employees; secured initial funds for the financing of working capital on favourable terms; and secured foreign markets. Thus, TMD Ai Gradačac (owned by PS CIMOS from Koper, Slovenia), a manufacturer of automotive components for the CIMOS industry, has quadrupled its exports and total production. Besides this company, foreign direct investors have invested in the metal production and processing sectors in Zenica, Banja Luka, Derventa, Travnik, Novi Travnik, Tešanj, Doboj, Tuzla, Sarajevo and Jajce.

Especially important for the future development of the $\mathrm{BiH}$ metal sector is the foreign direct investment of the Mittal Steel company in BH Steel. Mittal Steel, the world's leading steel producer with its headquarters in London, bought a majority stake in $\mathrm{BH}$ Steel from Zenica in the second half of 2004.

After the signing of the agreement on the privatisation of this company, significant investment was made in the creation of the conditions for the launching of integrated production. This project can not be realised in a short period of time; nor is it realistic to expect a large increase in employment. In fact, the employee structure of the company, which was inherited from the previous period, implied the necessity to dismiss older and less productive employees and replace them with younger and more productive ones. This process has already been initiated and it quickly resulted in increased productivity. The production of Mittal Steel Zenica doubled and, by means of the realisation of all planned investments until the end of 2009, production was envisaged to increase from 585000 tonnes per year to 2.2 million tonnes. Such an increase in pro- 
duction was intended to enable this company to become a major regional producer of steel and one of the most important exporters.

The current situation under which, after the privatisation of the Ljubija mine, the majority owner would export the extracted ore to central European countries will also be changed. The planned linking of the ore supplies of the Ljubija mine with production at Mittal Steel Zenica instead will provide a basis for connecting these two companies within $\mathrm{BiH}$.

In fact, it was the arrival in $\mathrm{BiH}$ of Mittal Steel that significantly changed the attitude of the most influential people in some of the most important European financial institutions, such as the EBRD and the EIB, in terms of changing the image of the $\mathrm{BiH}$ economy. The EBRD has recently approved a loan to Mittal Steel Zenica to an amount of $€ 25 \mathrm{~m}$. At the same time, this created the conditions for approving funds for the reconstruction of the $\mathrm{BiH}$ infrastructure as a necessary basis for increasing still further the interest of foreign investors in investment in $\mathrm{BiH}$. Indeed, three loans have been approved for the modernisation of $\mathrm{BiH}$ rail transport. The Mittal Steel investment is also likely to act as a direct basis for economic growth.

The joint stock company Aluminij Mostar, BiH's largest exporter, potentially represents one of the largest foreign direct investments in $\mathrm{BiH}$ and the region. The interest of foreign partners in this company is unquestionable and it is only a matter of time until a definitive agreement is reached on this particular, important privatisation with the most respected companies in the area of aluminium production and processing. In the past five years, Aluminij Mostar (907 employees) has not only increased exports by around $120 \mathrm{~m}$ Bosnian Marks (BAM), ${ }^{3}$ but has also come to represent a direct strategic base for the supply of key raw materials and semi-manufactured goods for the development of companies that recorded very high growth rates of exports and total income in the 2001-2005 period.

Thus, the major deficiencies which were identified and discussed in previous research studies, related to the almost complete division and lack of co-ordination between domestic manufacturers in the metal sector, have been partially removed. That is, a basis for the development of medium-sized enterprises has been gradually created, founded on integration with large manufacturers.

Significant factors that have influenced a lowering of the costs of the financing of working capital include the arrival of foreign banks in the BiH banking system and the major reduction in average interest rates. In the last four years, the annual interest rate was reduced from $30 \%$ to $8.85 \%$.

All these factors have created the basis for a very significant growth of production and total income, as well as for a resolution of the problems related to previouslyincurred debts and to the writing-off of obsolete technology (equipment) from the manufacturing process.

The metal production and processing sector is of key importance for the expansion of Bosnia and Herzegovina exports. Actually, according to official statistics, the total exports of $\mathrm{BiH}$ at the end of 1998 amounted to only BAM 1.2bn. In the following six years, exports increased to BAM 3.02bn (2004) and, in the last year, according to

3 At current exchange rates, BAM $1=€ 0.614$. 
preliminary data, total exports amounted to BAM 3.8bn. One of the leading export sectors of the $\mathrm{BiH}$ economy in the last three years was, in fact, the metal sector.

The competitive advantage matrix, developed on the basis of foreign direct investment, shows that the $\mathrm{BiH}$ metals sector has attracted interest from respectable global (VW, Mittal Steel, Citroen, Man-Humel, LNM, Ispaat) and regional (CIMOS, Prevent, TLM) companies. This has led to the inclusion of the $\mathrm{BiH}$ metal sector in the processes of globalisation and regionalisation in which competitiveness is not locally determined but dependent on the position of companies in the global and regional industry. This reminds us that the competitiveness of the metal sector can not be built on the potential of the 'double diamond' model if companies operating within its framework do not adopt an international orientation, be it an export or a regional orientation.

It is interesting that there is a number of entrepreneurs of local importance, but who harbour regional ambitions, who are investing in the $\mathrm{BiH}$ metal sector, mainly in smalland medium-sized enterprises. Especially prominent have been Slovenian entrepreneurs, who have acquired high skills in narrowly specialised businesses, such as the foundry industry, and who see opportunities in $\mathrm{BiH}$ for their further regional expansion. Such investors could represent an important target group in the implementation of strategies for the setting up of new small export-oriented companies in $\mathrm{BiH}$.

The domestic market is small, and supporting industries under-developed, so the development of the competitiveness of the metals sector would have remained very limited had it been tied exclusively to the 'single diamond' model. The potential domestic competitiveness of the metal sector will, in the future, relatively increase in the structure of the 'double diamond' model. It may thus be the case that the metals sector strengthens its potential for growth, with the model giving a focus to sources of competitive advantage in international competitiveness.

The promotion of foreign direct investment has proved to be necessary in achieving the regional competitiveness of the metal sector. It should, however, not discriminate against domestic investors, who play an important role in initiating entrepreneurship in the metal sector and in the building of international competitiveness through various forms of links with foreign partners, such as production co-operation, licensing, subcontracting and the like.

The promotion of foreign direct investment in the metal sector is necessary because it ensures:

- the inflow of technology, know-how and management skills into the country and their most efficient use through business internationalisation

- the incorporation of domestic companies into global and regional business marketing networks, thereby placing their competitiveness in the context of regional and global competitiveness governed by investor companies

- additional capital for investment aimed at increasing productivity and the competitiveness of companies.

The dominant markets for domestic companies are supplies and isolated products markets and, to a lesser extent, components and modules markets, as well as markets in other technologically-integrated products where higher value added is created. The target markets of the metal sector are the highly demanding EU ones, and this is a positive factor in efforts aimed at building competitiveness in the circumstances of the 
'double diamond' model of competitive advantage. The contribution of foreign direct investment to the building of competitiveness within this model is significant.

Some companies founded on foreign direct investment are already showing high competitiveness and the ability to generate new projects in $\mathrm{BiH}$ (Cimos, Prevent), while others are going through a difficult period of restructuring under the circumstances of high risks in the global market. These could not have been withstood were they to be operating within locally-based competition (Mittal Steel, Ispaat, Birač and others).

Research into the competitiveness of metal sector companies shows that there is no major correlation between competitiveness and the degree of export orientation of companies. This shows that the potential of the 'double diamond' model can not be used exclusively in the area of demand conditions and that, in order to achieve competitiveness, it is necessary to develop strategies and operations that will optimise the use of sources of competitive advantage in both the domestic and the international business arenas.

\section{Performance}

The large increase in production in the metals sector, which followed over the course of the next five years after the commencement of integrated production in Mittal Steel Zenica, on the one hand, and after the announced investment to double the production capacity of the joint stock company Aluminij Mostar on the other, will play a key role in the expansion of rail transport, as well as in the expansion of river transport by providing a basis for the increase of traffic through Brčko port. The approval of the EBRD and EIB loans was, in fact, based on the strategic plans for the development of this segment of the $\mathrm{BiH}$ economy as one of the cornerstones of its expansion, as well as of reducing the relative extent to which it lags behind countries in the region.

The largest share in total income in the last ten years was taken by the aluminium industry, with a $36.3 \%$ share; followed by metallurgy $(27.8 \%)$; the electrical industry $(17.4 \%)$; the automotive industry $(12.1 \%)$; metal processing $(5.8 \%)$; and, ultimately, tool making $(0.6 \%)$.

The largest single exporter is Aluminij Mostar, while the largest share of total exports in the metal and electrical sector is taken by the aluminium industry, with a $41.4 \%$ share; followed by metallurgy $(26.3 \%)$; the automotive industry $(17.4 \%)$; the electrical industry (11.8\%); metal processing $(2.8 \%)$; and tool making $(0.06 \%)$.

Total imports in this sector in 2009 accounted for $8.5 \%$ of the total amount of imports into $\mathrm{BiH}$ in that year. The largest importer was metallurgy, with a $28.2 \%$ share of total imports; followed by the electrical industry (23\%); the aluminium industry $(22.6 \%)$; the automotive industry $(21.3 \%)$; metal processing $(4.2 \%)$; and tool making $(0.5 \%)$.

The largest exporter to the EU market is the automotive industry, of whose products $79.4 \%$ go to the EU; followed by metallurgy (46.5 \%); and the aluminium (44.2\%).

Employment costs in 2009 ranged between BAM 25741 (Mann Hummel Tešanj) and BAM 322990 (Aluminij Mostar). The differences in employment cost are primarily determined by type of production, the degree of automation and the degree of restructuring that has been achieved. 
The average net wage in Bosnia and Herzegovina in 2009 amounted to BAM 662. The highest net wages in the sector are paid to employees in the aluminium industry, with an index of $186 \%$ of the average net wage in $\mathrm{BiH}$. The lowest net wages were paid to employees in the metal processing industry $(71 \%)$.

The average utilisation of production capacity is: $74.7 \%$ in the automotive industry; $51.9 \%$ in the metal processing industry; $80 \%$ in metallurgy; $71.2 \%$ in tool making; $61 \%$ in the electrical industry; and $80.5 \%$ in aluminium. Three-shifts working is organised by $25 \%$ of companies, whereas there is an equal share of $37.5 \%$ of companies operating either one or two shifts. All this data clearly shows the low degree of utilisation of production capacities in the metal and electrical industry.

Over $50 \%$ of the total number of companies in the metal and electrical industry use old equipment and obsolete technology, which significantly reduces their competitive ability; calls for huge investment in new technology; and poses a major obstacle to a more rapid development of this sector in the future.

\section{Future strategic objectives}

Research shows that $27.3 \%$ of companies in $\mathrm{BiH}$ do not have a short-term and/or a long-term development strategy, and that $68.8 \%$ of companies do not have any development functions. In the context of the industrial policy measures that will primarily contribute to an increase in the competitiveness of the metal sector and to the creation of business conditions in $\mathrm{BiH}$ that will be at least approximately equal to the standards of EU member states, we herewith emphasise the following potential strategic development objectives:

1. Accelerating the privatisation of state-owned companies

In companies where privatisation has not taken place, the first strategic objective is to determine property relationships.

2. Modernisation of the existing, and the introduction of new, equipment and technology

The metal and electrical sector in $\mathrm{BiH}$ does not occupy an enviable position in terms of the condition of its equipment and technology. This is the result of war destruction, as well as the years that have passed without investment in technology, manufacturing processes and new production programmes. Given that $47.6 \%$ of companies use old equipment while manufacturing is, in $57.1 \%$ of companies, based on obsolete technology, one of the priority objectives is the modernisation of existing technology and equipment, as well as the introduction of new, high technology equipment. For example, in the joint stock company FAD Jelah Tešanj, it is necessary to apply new technology for surface protection.

The trends globally are based on the introduction of new technologies, i.e. on the use of capital- and knowledge-intensive equipment and technology:

- highly automated and robotised processes

- information technology and digital communications

- new technological processes: high speed machining, laser processing, etc.

- new materials and new energy sources. 
$\mathrm{BiH}$ companies must enter the world of high technology and services, as well as modern management methods, thereby putting product quality into the foreground, if they want to be competitive on both the domestic and foreign markets. At the same time, the interests of workers and society as a whole must not be neglected.

The introduction of high technology requires significant investment; one of the ways to modernise existing, and/or introduce new, equipment and technology is through foreign direct investment. It is therefore recommended that competent institutions seek ways of finding and seizing these opportunities and adopting appropriate measures to encourage the introduction of high technology. At the same time, measures must be taken to provide for the necessary retraining of the workers that will be out of work due to the introduction of automated facilities.

1. Encouraging research and development activities, with universities at the centre

Via intensifying the level of co-operation with higher education institutions, it is necessary to establish and enhance communication with higher education institutions, which will contribute to a greater involvement of local staff in the process of the development of new products and technologies.

Given that the introduction of new high technology requires a higher level of knowledge, responsibility and awareness of workers, it is necessary first to provide for their retraining and additional training, and thereafter their continuing education, aimed at allowing them to master technical and technological novelties. Higher education institutions, as centres of research and development activities, can play an important role in providing additional training programmes.

2. Changing the export structure by means of increasing the degree of product finalisation

Domestic resources of aluminium and steel should be retained for domestic purposes because they, along with energy, constitute the 'golden triangle' for the development of industry. By means of the further processing of aluminium, it is possible to obtain new products for the automotive and electrical industry, which would open up the possibility for the formation of more favourable electricity prices for special customers.

Research into production programmes in the metal and electricals sector shows that there is a lack of foundries and only one steel castings foundry (Steel Foundry Tuzla). The modernization of foundries would significantly reduce imports of castings, while a widening of its product range would enable Steel Foundry Tuzla to serve the needs of the BiH energy sector.

Previous experience suggests that the unused potential of the metal sector is in the design and manufacture of tools. Forming a cluster of tool-makers would contribute to a more rapid development of this branch of the metal industry.

1. Increasing exports with the emphasis on market expansion (supported by State measures, implementation of duty free trade measures, passing of legislation that would encourage companies to export, etc.)

2. Applying international and, above all, EU regulations in the area of improving the quality of products and services 
With a view to increasing the competitiveness of companies, it is necessary to create the conditions for obtaining CE markings on products and for the introduction of ISO 9001: 2000, ISO 14001 and TS 16949: 2002 certificates, as well as for actually meeting the requirements imposed by these standards. It is necessary to monitor continually the measures implemented by the EU related to those products which are imported to or exported from $\mathrm{BiH}$.

1. Developing a system of continuous market research (e.g. through chambers of commerce).

2. Introducing information technology and digital communications (adopting measures to reduce provider costs and, at the same time, upgrade communications performance - speed, etc.).

3. Launching new projects ensuring shareholder value.

4. Designing campaigns to make business connections with the most attractive companies, encouraging the creation of clusters, industrial and business entrepreneurial zones, technology parks, etc.

5. Professional and enterprise licensing.

6. Adequate marketing services.

7. Interest-based networking of industrial companies and SMEs.

8. Institutions that should ensure knowledge and technology transfer should become market-oriented.

9. The Development Bank, as the institution that should provide access to finance on a more favourable basis, should be strengthened.

Achieving the strategic development objectives would, to a large extent, eliminate the weaknesses and threats in the development of industrial companies, and significantly increase their strengths and opportunities. The only variable resources are knowledge and skills, lifelong training, research, new technology and institutional infrastructure, and they provide us with opportunities for market competition. New technologies impose a new way of life, which requires the constant mastering of new forms of knowledge and the daily intake of an abundance of new information: high technology means running faster just to stand still.

\section{Summary and recommendations}

There is no doubt that the metal sector is of strategic importance to $\mathrm{BiH}$. In the last five years, this sector achieved export growth that was twice as fast as the average in the $\mathrm{BiH}$ economy. This sector also has a significant effect on import substitution in some important segments. In other words, the metal sector is one of the key sectors for resolving the problems of the large trade deficit of the $\mathrm{BiH}$ economy. That is why organised assistance on the part of the state - that is, the relevant ministries of the Council of Ministers and the entity governments - aimed at increasing productivity is very important to raising the achieved level of competitiveness.

It is in this context that we recommend the following measures:

- one of the priorities in $\mathrm{BiH}$ market integration should be the integration of the energy sector. So far, no significant progress has been made in this regard. The surplus electricity generated in one or both of the entities is not subject to regular exchange on an integrated $\mathrm{BiH}$ market. The regulatory agencies that have been 
established in co-operation with the Council of Ministers and the entity ministries should resolve this problem in the context of preparations for signing the Stabilisation and Association Agreement

- the monetary regime in $\mathrm{BiH}$ is based on the principle of a currency board, and so supporting exports by using monetary policy measures is not a realistic option in the next three-year period. That is why most of the measures which are aimed at supporting the export orientation and restructuring of the metal sector are based on fiscal policy

- the primary and necessary measure of fiscal policy, which can be implemented in a very short period of time, is the lifting of customs duties on the import of equipment for companies operating without foreign direct investment. The imposition of customs duties on equipment imports was one of the most paradoxical economic policy measures adopted in the previous period. Bearing in mind that equipment is a key part of companies' assets, having a significant impact as regards increasing productivity and the competitiveness of domestic manufacturers, the $\mathrm{BiH}$ parliament should amend this section of the Customs Policy Law through the expedited procedure, thereby putting domestic manufacturers in an equal position to companies which are owned by non-residents

- managers of companies in the metal sector suggest the need for a lifting of customs duties on the import of raw materials and semi-finished manufactured products, not only for companies owned by foreign direct investors but also for companies owned by residents. Companies that are exempt from the payment of customs duties on raw materials and semi-manufactured goods intended for export are confronted with relatively slow procedures for obtaining documents. This suggests the need for a simplification of procedures in these particular areas

- the existing structure of separate ministries, and sectors within the ministries responsible for industry, mining and energy sectors, in which the metals sector represents one of the most important parts, is not adequate and does not ensure either effective economic policy co-ordination or the integration of the $\mathrm{BiH}$ market in this segment. Therefore, one of the key measures in the future re-organisation of the administrative structure should be the establishment of a BiH Ministry of Industry, Energy and Mining, which would have the capacity to carry out a consistent economic policy

- additionally, the BiH Council of Ministers should establish a BiH Business Sector Advisory Board, thereby formally creating a partnership between economic policymakers and the business sector. This should play a key role in the implementation of measures aimed at improving the competitiveness of the $\mathrm{BiH}$ economy. The absence of an institutionalised form of partnership between economic policy-makers and key stakeholders from the business sector represents a serious limitation in communications between the government and the business community

- establishing social funds to address the status of surplus employees in metal sector companies which achieve significant export results, but which also sustain losses due to the number of their employees not being adapted to the requirements imposed by competition, should be one of the elements encouraging the initiation of a restructuring of such companies 
- establishing technology parks and centres for retraining and additional training in parts of former or current military barracks that will not be used for military purposes, carried out in co-operation with employment bureaus in both entities, would represent an activity that could contribute to solving the problem of insufficient knowledge and the lack of skilled and highly-skilled workers necessary for new technology solutions in metal sector companies

- with a view to enabling an analysis of quality and the meeting of international product quality standards in the area of metal production and processing, it is necessary to establish an institute for quality control and the certification of metal products intended for both domestic and foreign markets. The current situation, where there is no such institute, directly contributes to the presence of unfair competition in the domestic market and of domestic exporters facing complicated procedures when obtaining international certificates. The Institute of Metallurgy in Zenica has skilled staff and decades of experience in product quality control in this area, and so the BiH Council of Ministers should authorise this institution to provide quality control and product certification services across the territory of $\mathrm{BiH}$. 